\title{
Promising future for an elephant population - a case study in Burkina Faso, West Africa
}

\author{
Théophane E. Damiba and Ernest D. Ables
}

\begin{abstract}
Nazinga Game Ranch, which was established in 1979 in Burkina Faso and is the only one of its kind in the country, has achieved much success in reconciling wildlife conservation with the needs of local people. The ranch provides a refuge for elephants escaping harassment elsewhere but this creates problems for local people whose crops suffer elephant damage. Despite the problems, many villagers welcome the proximity of the ranch and its elephants and, while there are still problems to be solved - and funds needed to help solve them - the ranch is an excellent model for conservation action.
\end{abstract}

\section{Introduction}

Wildlife conservation programmes in developing nations across Africa have, in the past, often failed to take into account the social context in which they operate. Protected areas have been set aside with well defined administrative boundaries on paper. However, too few conservation strategies involve local people, despite the lack of funds to provide adequate personnel and logistics to enforce rules and regulations inside protected areas. The local people, conscious of these weaknesses, frustrated at being displaced to make room for parks and reserves, and bedevilled by wildlife depredations, especially by elephants, threaten government set-aside lands. Among the types of social pressures on these designated areas are: agricultural encroachment and domestic livestock invasion, fuel wood cutting, and poaching, for game meat or trade in wildlife products.

Burkina Faso has the largest elephant population in West Africa, estimated to be 4500 animals (Douglas-Hamilton, 1989). In the country's Nazinga Game Ranch (NGR), the elephant population has been increased by immigrants fleeing harassment in the Kabore Tambi National Park (KTNP), located $25 \mathrm{~km}$ north-east (Damez-Fontaine, 1987; Jachmann, 1987). There are nearly 300 elephants and 79 per cent of the population is under 15 years old, with a sex ratio approximating 1 male to 2 females (Damiba, 1991). Impacts on the woody vegetation in the NGR are so far minor, but elephants have started to raid the subsistence crops belonging to local communities surrounding the ranch. This young elephant population has a great potential for increase and more social impacts can be expected. This case study, beyond documenting elephant social impacts, reveals that around the ranch, unlike elsewhere, villagers are willing to cope with elephant depredations and even take an active part in the conservation of the species as long as they receive tangible benefits from the ranch. We feel that the NGR situation is an excellent example of the benefits of integrating local people into protected area management.

\section{The study area}

The Nazinga Game Ranch covers 806 sq km of tall-grass savannah in south-central Burkina Faso (Figure 1). Three river drainages provide thick riverine woodlands. Major wildlife species include: buffalo Synceros caffer, elephant Loxodonta africana, oribi Ourebia ourebi, common duiker Sylvicapra grimmia, redflanked duiker Cephalophus rufilatus, western 
hartebeest Alcelaphus buselaphus, kob Kobus $k o b$, roan antelope Hippotragus equinus, bushbuck Tragelaphus scriptus, waterbuck Kobus ellipsiprymnus, Bohar reedbuck Redunca redunca, wart hog Phacoc-hoerus aethiopicus, olive baboon Papio anubis and vervet (savannah) monkey Cercopithecus aethiops. There are no domestic livestock on the ranch lands.

The Nazinga Game Ranch is the only area in Burkina Faso where an attempt has been made to manage free-ranging wildlife species on a scientifically based, sustained-yield basis. It is a unique experiment in wildlife management in West Africa (IUCN-CDC, 1988). The ranch was established in 1979 to ensure protection of wildlife threatened by poaching and agricultural encroachment, to create jobs by integrating the local populations into management of the ranch, and to provide animal protein for local people through cropping of wild

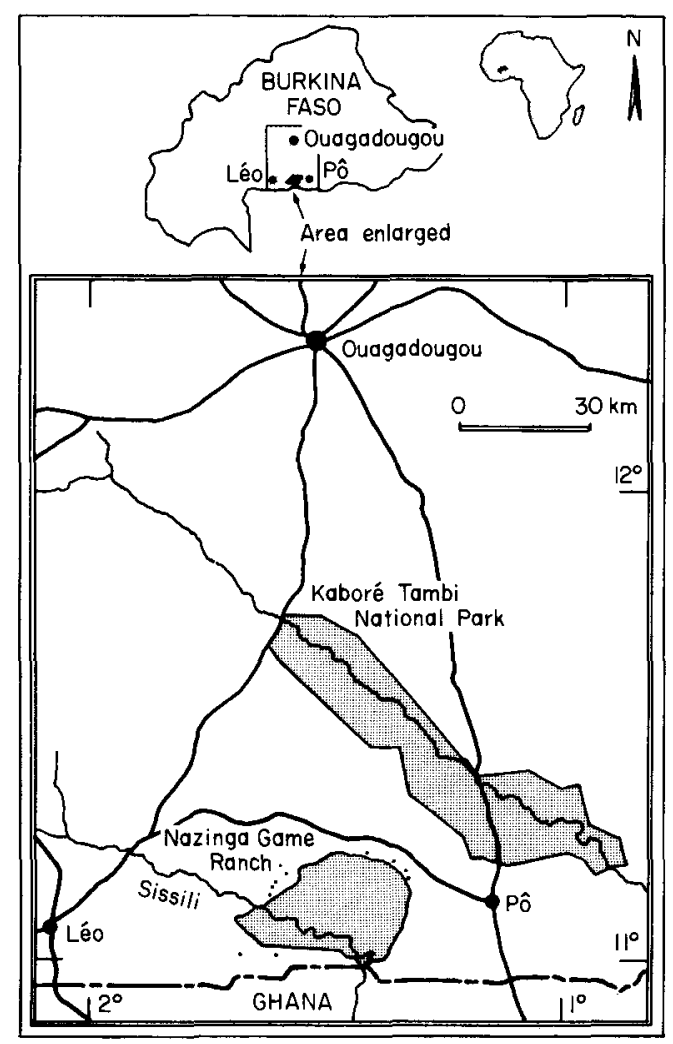

Figure 1. Location of the Nazinga Game Ranch (NGR) in Burkina Faso. (Adapted from IUCN-CDC, 1988.) game species. During the past few years tourist visits to the ranch have increased substantially and have become a major consideration in the management of the ranch. Game cropping continues, but is conducted in a manner that minimizes interference with wildlife viewing activities.

People around the NGR are settled in 13 villages and our study focused on 11 of these within $7 \mathrm{~km}$ (Figure 2). In 19902016 people inhabited these villages, with women accounting for 52 per cent of the population. Only 45 per cent of the population are 20 years old or more, 446 of them men (Table 1).

Subsistence farming is the main activity for local people. This farming system is extensive and based on 'slash and burn shifting cultivation' methods, using rudimentary equipment. The major crops are millet Pennisetum typhoides, sorghum Sorghum bicolor, corn Zea mays, a variety of local legumes, plus yams Dioscorea spp., sweet potatoes Ipomea patatas, peanuts Arachis hypogea and cowpeas Vigna unguiculuta. Villagers grow crops during the rainy season (May-October) and in the dry season (November-April), gather crops into granaries, trade crops and goods, fish and hunt, the latter usually illegally.

Infrastructure in these villages is very rudimentary. With the exception of Sia village, where a school is being built, there are no educational facilities. The water supply is limited to one or two wells in each village. For medical needs, the local people rely on the NGR medical personnel and facility because the nearest hospital is $55 \mathrm{~km}$ away.

Even though the NGR has brought benefits to the villages in terms of infrastructure, market opportunities and temporary jobs, it has also created a major drawback. Elephants are now increasing within the NGR and are damaging crop lands surrounding the ranch.

\section{Research objectives}

Our goal was to evaluate the social impacts of elephants on local communities around the NGR. Specifically, our objectives were to: document the type of elephant impacts and

ORYX VOL 27 NO 2 APRIL 1993 
Table 1. Demographic data of the villages near the NGR (percentage figures are in parentheses)

\begin{tabular}{|c|c|c|c|c|c|}
\hline \multirow[b]{2}{*}{ Village } & \multirow[b]{2}{*}{$\begin{array}{l}\text { Population } \\
(1985)^{*}\end{array}$} & \multicolumn{4}{|c|}{ Population of $1990+$} \\
\hline & & Total & Women $(52 \%)$ & Men (48\%) & $\begin{array}{l}\text { Men }(22 \%) \\
(, 20 \text { years old) }\end{array}$ \\
\hline \multicolumn{6}{|c|}{ Nahouri Province } \\
\hline Boassan & 118 & 138 & $70(51)$ & $68(49)$ & $34(25)$ \\
\hline Kontioro & 190 & 222 & $115(52)$ & $107(48)$ & $43(19)$ \\
\hline Kouna & 77 & 90 & $44(49)$ & $46(51)$ & $16(18)$ \\
\hline Natiédougou & 102 & 119 & $64(54)$ & $55(46)$ & $29(24)$ \\
\hline Saro & 112 & 131 & $69(53)$ & $62(47)$ & $24(18)$ \\
\hline Sia & 217 & 253 & $106(42)$ & $147(58)$ & $68(27)$ \\
\hline Waleme & 100 & 117 & $62(53)$ & $55(47)$ & $27(23)$ \\
\hline Wiri & 14 & 16 & $12(75)$ & $4(25)$ & $2(12)$ \\
\hline \multicolumn{6}{|l|}{ Sissili Province } \\
\hline Boala & 373 & 429 & $232(54)$ & $197(46)$ & $88(1)$ \\
\hline Kounou & 164 & 203 & $114(56)$ & $89(44)$ & $45(22)$ \\
\hline Tassyin & 241 & 298 & $159(53)$ & $139(47)$ & $70(23)$ \\
\hline Total & 1,708 & 2,016 & 1,047 & 969 & 446 \\
\hline
\end{tabular}

* Direction de la Démographie (1988).

+ Projected from growth rate (Direction de la Démographie, 1985).

the traditional methods being used by local people to mitigate them; identify the migration pathways of elephants outside the ranch; obtain local people's opinions and perceptions about elephant conservation and the NGR efforts to protect elephants and other wildlife species; and finally, to investigate the extent of elephant poaching in the area.

\section{Methodology}

We used a purposive sampling scheme (Selltiz et al., 1976) to define the sampling units. The target group was men over 20 years (Table 1), who were likely to be heads of families, holders of crop lands, hunters, and the most influential people in the hierarchy of their society.

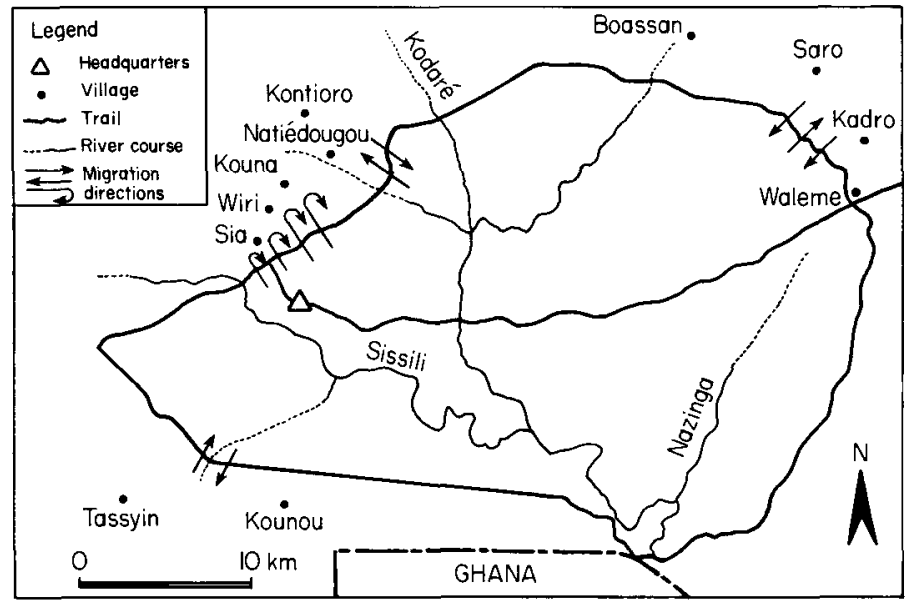

Figure 2. Villages around the Nazinga Game Ranch. 
Table 2. Number of people interviewed in each group

\begin{tabular}{|c|c|c|c|}
\hline Village & $\begin{array}{l}\text { People } \\
\text { surveyed }\end{array}$ & $\begin{array}{l}\text { Target } \\
\text { group } \\
(1990)\end{array}$ & $\begin{array}{l}\text { Per cent } \\
\text { sampled }\end{array}$ \\
\hline \multicolumn{4}{|c|}{ Nahouri Province } \\
\hline Boassan & 18 & 33 & 55 \\
\hline Kontioro & 16 & 42 & 38 \\
\hline Kouna & 4 & 16 & 25 \\
\hline Natiédougou & 9 & 28 & 32 \\
\hline Saro & 6 & 24 & 25 \\
\hline Sia & 7 & 66 & 11 \\
\hline Waleme & 16 & 26 & 61 \\
\hline Wiri & 1 & $1^{*}$ & 100 \\
\hline \multicolumn{4}{|l|}{ Sissili Province } \\
\hline Boala & 14 & 84 & 17 \\
\hline Kounou & 13 & 43 & 30 \\
\hline Tassyin & 17 & 68 & 25 \\
\hline Total & 121 & 431 & 28 \\
\hline
\end{tabular}

* This figure has been corrected with our observations in the field.

We were able to interview 28 per cent of the 1990 target population, a total of 121 people (Table 2).

For group meetings, we used the focused interview (Bailey, 1982). The questions were open-ended in order to encourage conversations and allow respondents to offer comments on relevant information. The visit to each village was scheduled at the convenience of the local people. The interviews were conducted in local languages and procedures were the same in all villages surveyed.

\section{Results}

\section{Elephant impacts in the villages}

Elephant impacts to date are limited to six of the 11 villages surveyed. Table 3 summarizes the information collected in these villages. According to the villagers, elephant impacts peaked in the early (May-July) and late (September-October) rainy seasons. In the early dry season elephants damaged dry standing crops in the villages of Natiédougou and Kontioro. The most frequently damaged crops are sorghum, millet, corn, yams, sweet potatoes and peanuts. During the dry season, elephants come to browse on local tree species of Acacia seyal, Parkia biglobosa, Vitellaria paradoxa, Vitex doniana, and sometimes Isoberlinia doka, in the villages of Wiri and Sia. Occasionally, elephants attempt to knock down millet granaries in the village of Sia. The group sizes of raiding elephants are not well known because villagers' reports were based on tracks or extent of damage during nighttime raids.

\section{Elephant migration pathways}

From discussions with the villagers, elephants appear to have three migration pathways within the villages (Figure 2). The first one is located on the north-eastern border of the NGR and goes through the villages of Saro and Waleme. Elephants from the NGR follow this pathway when moving towards the

\begin{tabular}{|c|c|c|c|}
\hline \multirow[b]{2}{*}{ Village } & \multicolumn{3}{|c|}{ Elephant damage } \\
\hline & $\begin{array}{l}\text { Frequency } \\
\text { per year }\end{array}$ & Period & Type \\
\hline Kounou & 5 & Rainy season & All crops \\
\hline Kontioro & 5 & Rainy season & $\begin{array}{l}\text { All crops } \\
\text { Early dry season }\end{array}$ \\
\hline Natiédougou & 6 & Rainy season & $\begin{array}{l}\text { All crops } \\
\text { Early dry season }\end{array}$ \\
\hline Kouna & 10 & Rainy season & All crops \\
\hline Wiri & $12-15$ & Year round & All crops \\
\hline Sia & $11-17$ & Year round & $\begin{array}{l}\text { All crops } \\
\text { Trees } \\
\text { Millet granaries }\end{array}$ \\
\hline
\end{tabular}

Table 3. Elephant impacts in the villages 
KTNP for short periods, of no more than 2 weeks, after which they return by the same pathway. This type of migration takes place in the early rainy season and may occur three or more times a season. The second pathway is located in the south-western part of the ranch and passes through the villages of Kounou and Tassyin. It is used by elephants travelling towards the border with Ghana and back again. The third migration pathway passes through the villages of Natiédougou and Kontioro in the western part of the ranch. Year round, elephants from the NGR follow this pathway for short excursions with destinations that remain unknown.

\section{Local strategies for reducing elephant impacts}

Local strategies to keep elephants away from crop lands are primitive, such as making any kind of noise, lighting wood stacks around the crop lands, throwing rocks with catapults, clearing a large strip of land around the crop lands to deprive elephants from approach cover, or simply sleeping in the crop fields to guard them from elephants. The most innovative and probably the most expensive strategy comes from the villagers of Sia and Wiri. In these two villages, some farmers hang lighted kerosene lamps on wooden poles around their fields to keep elephants away.

\section{Villagers' perceptions of elephant conservation}

In three of the 11 villages surveyed, people thought that protecting elephants was not worthwhile. For the group surveyed in Saro village, elephants are not considered useful at all because they are non-game species and threaten farm crops. Also, for the villagers in Kouna and Wiri elephants are probably valuable only to the ranch that protects them.

In the other eight villages, most people perceive that elephants are useful to the area in two ways. First of all, the NGR, which protects elephants and other wildlife species, creates temporary jobs for local people during the dry season. With the exception of the group interviewed in Waleme, people from the other villages had a more specific opinion about ele- phants. They stressed the fact that elephants are part of their cultural heritage. They welcomed the NGR initiative because future generations will have the chance to see elephants. The villagers in Waleme, on the other hand, along with the group in Kounou, expressed another opinion. Protecting elephants in the area will make them known to people from other parts of Burkina Faso and the rest of the world where elephants have disappeared.

\section{Villagers and the NGR: their opinions, concerns and expectations}

Overall, villagers viewed the establishment of the NGR in the area as socially and economically positive. Availability of local jobs has partially stemmed the emigration of young adults out of the area. Medical services are available on the ranch, and are especially appreciated when emergencies arise. Diets are enhanced by animal protein from game cropping operations and from fishing allowed in rivers on the ranch. The presence of tourists has opened up opportunities to sell local crafts and thus a cottage industry is developing. Villagers perceived that the presence of the ranch makes the area known so that it receives more favourable consideration by local administrative and political structures. Also, international development organizations have started exploring the area. Finally, ranch personnel assist surrounding villages in managing game bird-hunting operations.

However, whether people recognized that elephants are useful or not, the majority expressed a common concern: what will happen to their crop lands with an increased elephant population inside the NGR? The villagers are expecting the NGR administration to help them to cope with elephants more effectively. They suggested that compensation should be given to all farmers that have their crops damaged. They hoped that the NGR would find solutions to prevent elephants from going outside the ranch limits because elephants are unpredictable. Villagers around the NGR also thought that some of their administrative and local economic problems, such as the lack of infrastructure or facilities (e.g. dams), could be 
solved through the NGR. They also requested material support and assistance from the ranch to manage the village hunting zones around the ranch effectively.

\section{The elephant poaching problem}

The interviews revealed that some sensitive issues, such as elephant poaching, could not be reliably evaluated. In all the villages surveyed, people pointed out that poaching has not been a problem in their neighbourhood. The villagers of Tassyin were more specific, stressing the fact that they would not allow poaching in the ranch because they should be the first beneficiaries of elephants and the other wildlife species in the area. In Sia, the villagers said that any suspicious hunter in their neighbourhood is routinely reported to the ranch.

\section{Discussions, conclusions and recommendations}

Villagers' perceptions of elephant conservation or the usefulness of the species fall into two groups. The first comprises the three villages where the people interviewed did not regard elephants as useful. These are the people who receive the least benefit from the ranch. They either live far from the ranch headquarters (Saro), or they have few young people that would qualify for temporary jobs on the ranch (Wiri), or they do not have easy access to the ranch facilities and have been questioned and/or arrested for poaching (Kouna and Koumbili). The second group, the vast majority, has a positive attitude towards elephant conservation and the NGR because of the benefits. People from their communities work as seasonal employees on the ranch and Sia village, is getting a school through the ranch. Medical assistance, free transport to the nearest cities and authorized fishing are some of the benefits that the villages in this group receive. Interestingly enough, people from the village that suffers the most elephant depredations (Sia) are in this category.

We could not get reliable information on poaching because it is a strongly reprehended crime and some members within the surveyed groups may have been involved. Therefore, suspicions about the potential use of their answers could explain their reluctance to talk. However, reports from the NGR administration indicate that elephant poaching exists and two to five elephants are killed each year by local poachers, primarily for meat. Even though poaching pressure on the NGR elephant population is minor, efforts have been geared towards eradicating this crime completely because of the danger of it growing with time.

Given the will and the positive attitudes of local people towards elephants, and despite elephant depredations, an opportunity is created for a promising conservation strategy that involves villagers' participation. The factors that drove these elephants from the national park to the NGR are not likely to change in the near future, nor can migration corridors be established easily without strong political will, high costs of resettling people, changing traditional habitats of elephants, and co-operation of intergovernmental agencies. In the meantime elephants will inhabit the ranch and it is the responsibility of the ranch to deal with elephant depredation issues and maintain public support.

We recommend that elephant depredations on crop lands and human activities around the ranch are monitored on a long-term basis. Effectively managed village hunting areas around the NGR, under the supervision of the ranch, should act to provide a larger buffer zone for the ranch. They will also help to prevent agricultural land expansions towards the ranch and provide legally cropped game meat and substantial revenues to the villages from hunting fees. Moreover, with regular patrols by villagers, they may successfully deter poaching as well as reducing ranch expenditures for antipoaching units. In addition, the NGR should provide incentives other than jobs, such as compensation to the farmers that have their crops damaged by elephants. Benefits from game cropping or tourism revenues could be also shared with the villages surrounding the ranch in order to build more 
public support and contribute to improvement of living conditions. Finally, and most important of all, the NGR should design conservation education programmes for the villagers in order to increase their awareness of the various activities taking place within the ranch, and the importance of natural resource conservation. The more the villagers are informed, the more effective will be their participation for the sake of the elephants and other wildlife. We believe that building public support and motivating the local people is the only way to create and maintain positive attitudes towards the NGR. As Richard Leakey, Kenyan Director of Wildlife Management, stated, 'Unless we can make wildlife conservation profitable for all peoples, we cannot save our elephants for the future' (Grosvenor, 1990).

However, implementation of all these recommendations calls for funds that the NGR, which has been a self-sustaining institution since November 1990, cannot afford. Nevertheless, some additional programmes involving local people can be put into practice. Any achievement in this sense is a step towards a sound conservation strategy for this elephant population and other game species on the ranch. If nothing is done in this social context, which is familiar to other African countries that have constant population pressure on their lands, a negative attitude by the local people will develop and intensify.

In conclusion, the Naginza experience provides an excellent example of integrating conservation of a threatened species with a game ranching experiment that provides protein and a source of revenue and other amenities to local people. The result is a promising future for the ranch and the elephant because of the willingness of local people to participate in a positive and supportive manner.

\section{Acknowledgments}

We express our sincere gratitude to the USAID mission in Ouagadougou, Burkina Faso, for funding this research in the Nazinga Game Ranch; the Ministry of Environment and Tourism in Burkina Faso for authorizing needed support of equipment and personnel; the administration of the Nazinga
Game Ranch; and the villagers that participated in our interviews. Our special thanks to Dr W. J. Mclaughlin from the Department of Wildland Recreation and Tourism in the College of Forestry, Wildlife and Range Sciences at the University of Idaho for suggestions on the research methodology.

\section{References}

Bailey, K.D. 1982. Methods of Social Research, 2nd edn. The Free Press, New York, NY, 540pp.

Damez-Fontaine, I. 1987. Etude des Parametres de la Population d'Eléphants à Nazinga. Ministère de l'Environnement et du Tourisme, Ouagadougou, Burkina Faso, 34pp.

Damiba, T.E. 1991. Size, Impacts and Managerial Implications of the Nazinga Game Ranch Elephant Population in Burkina Faso, West Africa. M.S. Thesis, University of Idaho, USA.

Direction de la Démographie. 1985. Deuxième Recensement Général de la Population du 10-20 Décembre 1985. Principales Données Définitives. Ministère du Plan et de la Coopération. Institut National de la Statistique et de la Démographie, Ouagadougou, Burkina Faso, p. 9.

Direction de la Demographie. 1988. Recensement Général de la Population de 1985. Structure par Age et Sexe des Villagos du Burkina Faso. Ministère du Plan et de la Coopération. Institut National de la Statistique et de la Démographie, Ouagadougou, Burkina Faso. pp. 166-263.

Douglas-Hamilton, I. 1989. Overview of Status and Trends of the African Elephant. Report of the Ivory Trade Review Group (ed. S. Cobb). International Development Group, Oxford.

Grosvenor, G.M. 1990. Will the ban on ivory trade save Africa's elephants? Natl. Geogr. 178 (5), Editorial.

IUCN-CDC. 1988. Utilisation Rationnelle de la Faune et Réhabilitation d'un Milieu dégradé en Afrique de l'Ouest. Etude d'évaluation du Ranch de Nazinga. Rapport de mission, Ougadougou, Burkina Faso, $48 \mathrm{pp}$.

Jachmann, H. 1987. Numbers, Distribution and Movements of the Nazinga Elephant. Nazinga Special Reports Series C. No.17. Ministère de l'Environnement et du Tourisme, Ougadougou, Burkina Faso, 30pp.

Selltiz, C., Wrightsman, L.S. and Cook, S.W. 1976. Research Methods in Social Relations, 3rd edn. pp. 511-563. Holt, Rinehart and Winston, Inc. New York.

T. E. Damiba, c/o Ernest D. Ables, Department of Fish and Wildlife Resources, College of Forestry, Wildlife and Range Sciences, University of Idaho, Moscow, Idaho 83843, USA. 